solutions in chloroform behaved in a very irregular and surprising way; the mutarotation in this solven: seemed sometimes to "hang fire" until set going by some accidental stimulus. These observations were evidently important as proving that isomeric change was not spontaneous, even after the nitrocamphor had been dissolved. But for ten years no explanation was forthcoming to show why this phenomenon was observed in chloroform and in chloroform only. About five years ago, however, an arrest of isomeric change was again observed in the case of chloroform solutions to which a trace of acid had been added. These solutions (the rotatory power of one of which "held up" absolutely during twenty-four days) acquired a pungent and horrible odour, and had evidently undergone marked decomposition. It was not long before the odour was recognised as being due to carbonyl chloride-a well-known and (in anæsthetic chloroform) a dangerous impurity, formed by oxidation of the chloroform according to the equation-

$$
\mathrm{CHCl}_{3}+\mathrm{O}=\mathrm{COCl}_{2}+\mathrm{HCl} \text {. }
$$

This substance has the property of attacking ammonia and organic bases, such as piperidine, and converting them into neutral ureas, as shown by the equations:-

$$
\begin{gathered}
\mathrm{COCl}_{2}+2 \mathrm{NH}_{3}=\mathrm{CO}\left(\mathrm{NH}_{2}\right)_{2}+2 \mathrm{HCl}, \\
\mathrm{COCl}_{2}+2 \mathrm{NC}_{5} \mathrm{H}_{11}=\mathrm{CO}\left(\mathrm{NC}_{5} \mathrm{H}_{10}\right)_{2}+2 \mathrm{HCl} .
\end{gathered}
$$

The next step was obviously to try to arrest the isomeric change by the addition of carbonyl chloride to a solvent which did not naturally contain it. This was done with marked success. A solution of nitrocamphor in purified ether showed a change of rotatory power extending over about a day; by the addition of carbonyl chloride the period was increased to eighteen days in a glass vessel, and to sixty-one days when a silica vessel (free from alkali) was used to contain the solution. In the case of benzene, to which acetyl chloride was added, the period was increased from sixteen days to sixty-four days in glass, and to two years in a silica vessel. Finally, by the addition of carbonyl chloride to a solution of nitrocamphor in benzene contained in a silica vessel the period was increased from sixteen days to six years.

\section{Action of Light.}

A convenient method of studying the effect of light on isomeric change has recently been devised in which the polarimeter plays a leading part. The solution to be studied was enclosed in a silica tube, surrounded by a silica water-jacket, and exposed to the light from a silica mercury-lamp. In seven cases out of nine, however, no acceleration whatever could be detected as a result of this extremely powerful "insolation."

I have attempted to give some account of a few instances in which polarised light has been applied to the solution of chemical and physical problems. In each case the observations have taken the form of measurements of rotatory polarisation. Measurements such as these have supplied to the chemist a key which has enabled him to unlock the strongroom in which many of the secrets of molecular structure were stored. The physicist, too, following in the footsteps of Faraday, has found in rotatory polarisation a link between the sciences of magnetism and optics, and has obtained valuable hints as to the way in which light is propagated through matter. The hundred years which have elapsed since Biot announced his great discovery have therefore served only to enhance its brilliancy, and to reveal it as one of the most illuminating disclosures even of the splendid period in which it was made.

$$
\text { NO. } 2282 \text {, VOL. 9I] }
$$

\section{UNIVERSITY AND EDUCATIONAL} INTELLIGENCE.

Cambridge.-At Emmanuel College the following awards have been made for post-graduate research :Studentships: W. N. Benson (petrology), 75l., for half-year only; J. Macdonald (the development of Plato's ethics), rzol.; G. Matthai (continuation of research on the comparative anatomy of corals), $150 l$. Grants from the research studentship fund: $R$. T. Beatty (the energy of Röntgen rays), $25 l$., for one term only; J. H. Burn (biochemistry), 50 l.

LeEds.-Mr. E. L. Hummel has been appointed professor of mining. Mr. Hummel is a son of the late Prof. Hummel, and was educated at Leeds and in Austria. He has had much practical experience in the Yorkshire coalfield and in South Africa with the Vereeiging Estates Company.

Mr. Walter R. Crawford, of Tullyhogue, co. Tyrone, Ireland, has been appointed live stock officer for Yorkshire under the scheme for the improvement of live stock which has been inaugurated by the Board of Agriculture, with the aid of funds set aside by the Development Commissioners. Mr. Crawford has been a chief inspector under the live stock improvement scheme of the Department of Agriculture for Ireland, and is an authority on the breeding of shorthorns and on the work of milk record associations.

LONDON.--An important correspondence between the University authorities and Lord Haldane with reference to the new site for University headquarters has been published. Lord Haldane, in a letter dated June 6 , states that he is willing to try again to interest the donors who were prepared in March to acquire the Bedford Estate (British Muscum) site for the University. In reply, the Vice-Chancellor raised the questions of the provision of funds for rates and taxes, and for buildings, and of securing an option for additional land in the neighbourhood for extensions. He also inquired whether it would be possible to close the central road between the buildings to traffic. Lord Haldane, in a letter dated July $I_{3}$, was able to give satisfactory assurances on these points. The sites committee of the University have decided to postpone further consideration until a conference is arranged with the London County Council.

At the meeting of the Senate on July 16 , the D.Sc. degree was granted to Mr. I. C. Chapman (King's College) for a thesis on secondary Röntgen radiation to Dr. G. C. McK. Mathison (University College) for a thesis on the action of asphyxia upon nerve centres; and to Mr. J. Johnstone for a thesis entitled "Tetrarhynchus Erinaceus, van Beneden--I., Structure of the Larva and Adult Worm."

Sir Harry Waechter has offered 30ol, a vear for five years for a department for the treatment of disease by vaccine therapy at University College Hospital.

Grants amounting to $375 l$. for $1913^{-1} 4$ have been made to the following out of the Dixon Fund, for the assistance of various researches:--The Brown Animal Sanatory Institution, Prof. G. Barger, Mr. Morley Dainow, Mr. P. E. Lander, Miss Constance Leetham, Dr. Martin I.owry, Dr. Geoffrey Martin, Mr. J. W. Mcleod, and Mr. J. A. Picka-d.

Prof. John LalRd, professor of logic in the Dal housie University, Halifax, Nova Scotia, has been appointed to the chair of logic and metaphysics in the Queen's University, Belfast, in succession to the late Prof. Park. 
AN anonymous donor has given $500 l$. to the SouthEastern Agricultural College, Wye, for the extension of the research department, and the Development Commission is recommending a grant of 6oool. for the completion of the new college buildings. The governors have decided upon the erection of the buildings at the Fruit Research Station at Malling, the land for which (twenty-two acres) has been purchased by the Kent County Council.

THE following benefactions, among others, we learn from The Times, have been left to the British Academy by the late Miss Henriette Hertz:-20ool. for an annual lecture, investigation, or paper on a philosophical problem, or some problem in the philosophy of Western or Eastern civilisation in ancient and modern times bearing on the phenomena of life in relation to eternity; Ioool. for an annual public lecture on some master mind, considered individually with reference to his life and work, specially in order to appraise the essential elements of his genius, the subjects to be chosen from the great philosophers, artists, poets, musicians; and roool., the income of which is to be used to promote the publication of some philosophical work or to reward some meritorious publication in the department of philosophy. Miss Hertz also left the sum of ${ }^{5} 500 l$. to Girton College, the income to be used for the endowment of archæological research.

THE Board of Agriculture and Fisheries has awarded research scholarships in agricultural science of the annual value of i5ol., tenable for three years, to the following candidates, viz. :-E. W. Barton (Wales), economics of agriculture; W. Brown (Edinburgh), plant pathology; Miss E. C. V. Cornish (Bristol), dairying; F. L. Engledow (London), genetics; E. J. Holmyard (Cambridge), plant nutrition and soil problems; R. C. Knight (London and Bristol), plant physiology; F. J. Meggitt (Birmingham), agricultural zoology; H. Raistrick (Leeds), animal nutrition; G. O. Sherrard (Dublin), grenetics; $T$ Trought (Cambridge), genetics; G. Williams (Wales), animal nutrition; S. P. Wiltshire (Bristol), plant pathology. The Board has also awarded Miss T. Redman (London), a scholarship in dairying, tenable for two and a half years, to fill a vacancy caused by the resignation of a former scholar. The scholarships have been established in connection with the scheme for the promotion of scientific research in agriculture, for the purposes of which the Treasury has sanctioned a grant to the Board from the Development Fund; they are designed to provide for the training of promising students under suitable supervision with a view to enable them to contribute to the development of agricultural science.

The May issue for this year of the Johns Hopkins University Circular takes the form of the University Register for 1912-13. The volume contains an interesting historical introduction, which points out that the Johns Hopkins University was founded by a merchant of Baltimore, Johns Hopkins, who bequeathed the greater part of his estate for the establishment of a university and a hospital. The University was incorporated on August 24, 1867. Instruction began in $\times 876$, in which year President D. C. Gilman, from the University of California, was appointed first president, and remained in office for twenty-five years, being succeeded in 1901 by President Remsen, who resigned last year. The original endowment of the University amounted to somewhat more than $600,000 l$. This has been supplemented by several gifts, including the Endowment Fund of 1902 $(200,000 l$.$) , the John W. McCoy Fund (100,00ol.), and$ the Garrett Fund of $60,000 l$., in addition to many NO. 2282, VOL. 9I] other large sums. The income-bearing funds have a book value of more than $\mathrm{r}, 000,000 \mathrm{l}$, and the real estate and buildings, books, scientific apparatus, and general equipment are valued at more than 450,000 l. The assets of the University have thus a total value of a million and a half sterling. By Act of the Legislature of Maryland, at its session of 1912, the sum of $120,000 l$. was granted for the purpose of constructing and equipping buildings for a school of technology as a department of the University, with an annual appropriation of $10,000 l$. for maintenance.

THE Government's education policy was outlined by Mr. J. A. Pease, President of the Board of Education, in introducing in the House of Commons on Tuesday a "Bill to amend the law in respect to grants in aid of building, enlarging, improving, or fitting up elementary schools." In the course of his remarks, Mr. Pease said that the defects of our so-called national system of education are two-it is not national and it is not a system. The age at which compulsory attendance at school ceases under the existing law is too early; and to allow children to leave school at the age of from twelve to fourteen years, and leave them to forget what they have learned, is to neglect national responsibility. One main purpose of the Government is to organise intermediate education - that is, all classes of education from the elementary school and the university-by extending the powers and duties and adding to the resources of local education authorities. Further duties of these authorities must be accompanied by further and substantial assistance from the State. Out of $29,834,000 l$. spent on education in I9II-12, $14,186,000 l$. was obtained from the rates and I3,648,00ol. from Exchequer grants. The increase in expenditure since $1905^{-6}$ has been $3,500,000$. drawn from the rates and $1,000,000 l$. from grants, or out of every additional ol. required in the last six years $7 l$. had been found by the ratepayers and $2 l$. by the taxpayer. The demand which the ratepayer has for further relief for the taxpayer must, therefore, be admitted. As regards higher education, there will be no interference with the independence of the universities or with the government of training and technical colleges. The principles of the proposed legislation will be the arbitrary provision of intermediate education for all who desire it, placing it within the reach of all classes, and the coordination of such provision between authorities to prevent overlapping. Local authorities will have the duty imposed upon them of affording children during the latter years of elementary-school life opportunities of obtaining such instruction of a more advanced character than that given in the ordinary public elementary schools as may be thought suitable to the circumstances of the children. For this purpose the limit imposed by the Act of 1902 on the amount that might be raised by way of rates for the purposes of higher education will be removed. To give effect to the proposals of the Government, will require a large and substantial addition to the sum at its disposal, which will rise progressively from the first, second, third, and subsequent years. The forecast, of which no details can yet be given, includes provision for the universities, provision for the reconstitution of London University, and provision for the maintenance of increased secondary and technical schools.

\section{SOCIETIES AND ACADEMIES. DUBLIN.}

Royal Irish Academy, June 23.-Dr. F. A. Tarleton in the chair.-H. Ryan and Rev. J. M. Dunlea : Unsaturated diketones. I. By the condensation of 